\title{
Copper Gluconate
}

National Cancer Institute

\section{Source}

National Cancer Institute. Copper Gluconate. NCI Thesaurus. Code C80050.

The orally bioavailable copper salt of D-gluconic acid. In addition to its roles as an enzyme cofactor for cytochrome $\mathrm{C}$ oxidase and superoxide dismutase, copper forms complexes with the thiocarbamate disulfiram (DSF) forming DSF-copper complexes, which enhances the DSF-mediated inhibition of the $26 \mathrm{~S}$ proteasome; proteasome inhibition may result in inhibition of cellular protein degradation, cessation of cell cycle progression, inhibition of cellular proliferation, and the induction of apoptosis in susceptible tumor cell populations. 